\title{
Bio-kerosene and Bio-gasoil from Coconut Oils via Hydrocracking Process over Ni-Fe/HZSM-5 Catalyst
}

\author{
Muhammad Al-Muttaqii, Firman Kurniawansyah, Danawati Hari Prajitno, \\ Achmad Roesyadi*
}

Chemical Reaction Engineering Laboratory, Department of Chemical Engineering, Faculty of Industrial Technology, Sepuluh Nopember Institute of Technology, Surabaya, 60111, Indonesia

Received: $16^{\text {th }}$ May 2018; Revised: 18 th December2018; Accepted: 22th December 2018; Available online: 30th April 2019; Published regularly: 1st August 2019

\begin{abstract}
In this study, hydrocracking of coconut oil over Ni-Fe/HZSM-5 catalyst was carried out in a batch reactor under different reaction temperature. Coconut oil is proposed as one of the potential feedstock for biofuel production. The Ni-Fe/HZSM-5 catalyst was prepared by incipient wetness impregnation method. The characterization of Ni-Fe/HZSM-5 catalyst by X-Ray Diffraction (XRD), Scanning Electron Microscopy-Energy Dispersive X-ray (SEM-EDAX), and Brunauer-Emmett-Teller (BET). The chemical composition of biofuel was analyzed by Gas-Chromatography-Mass Spectrometry (GC-MS). The results from the GC-MS analysis showed that the hydrocracking reaction over $10 \%$ (Ni-Fe)/HZSM-5 catalyst at temperature of $375{ }^{\circ} \mathrm{C}$ obtained the highest hydrocarbon content (contained $49.4 \% \mathrm{n}$-paraffin, 26.93 $\%$ isoparaffin, $3.58 \%$ olefin) and the highest yield of bio-gasoil $38.6 \%$ in the biofuel liquid hydrocarbon. Pentadecane $\left(\mathrm{n}-\mathrm{C}_{15}\right)$ and heptadecane $\left(\mathrm{n}-\mathrm{C}_{17}\right)$ were the most abundant hydrocarbon compounds in biofuel liquid hydrocarbon. Decarboxylation and/or decarbonylation was the dominant reaction pathways in this process. Based on the result, the reaction temperature had a significant effect on the distribution of biofuel composition and yield of biofuel from coconut oil. Copyright (c) 2019 BCREC Group. All rights reserved
\end{abstract}

Keywords: Hydrocracking; Coconut Oil; Ni-Fe/HZSM-5 Catalyst; n-Paraffin

How to Cite: Al-Muttaqii, M., Kurniawansyah, F., Prajitno, D.H., Roesyadi, A. (2019). Bio-kerosene and Bio-gasoil from Coconut Oils via Hydrocracking Process over Ni-Fe/HZSM-5 Catalyst. Bulletin of Chemical Reaction Engineering \& Catalysis, 14 (2): 309-319 (doi:10.9767/bcrec.14.2.2669.309-319)

Permalink/DOI: https://doi.org/10.9767/bcrec.14.2.2669.309-319

\section{Introduction}

The increase of toxic gases affects earth atmospheric condition greenhouse generated by fossil fuels consumption. Therefore, it is necessary to find an alternative energy to replace the fossil fuel resources which has efficient and sustainable sources with lower emissions. Biomass is expected to be a renewable source in the near

* Corresponding Author.

E-mail: aroesyadi@yahoo.com (A. Roesyadi);

Telp: 031-5937968, Fax: 031-5968153 future because it has a great potential for production biofuel [1,2]. In this context, the biofuels have been proposed as an alternative substitute for fossil fuels [3]. Vegetable oils are excellent feedstocks for production of renewable energy because they contain fatty acids in the proper carbon range (in most oil from $\mathrm{C}_{14}$ and $\mathrm{C}_{20}$ ) that can be easily removed by hydrocracking [4,5]. Coconut oil (Cocos nucifera) is proposed as one of the most potential feedstocks for production of biofuel because its seed contains high oil yield 63-65\% [6]. In addition, the conversion of vegetable oil via hydrocracking process has been 
known as one of the most promising methods that can directly convert into biofuels. The advantages of this process is introduction of hydrogen gas (remove oxygen atoms in the form of $\mathrm{H}_{2} \mathrm{O}, \mathrm{CO}$, and $\mathrm{CO}_{2}$ ), then to achieve high liquid yields known as biofuel straight chain alkanes and high cetane number of the product as main product (up to of $75 \%$ ) $[1,7,8]$.

Researchers have reported the conversion of vegetable oils into biofuel. Hydrocracking of palm oil to jet biofuel over Ni/SAPO-34 catalyst was produced the highest alkane selectivity of $65 \%$, and lowest arene selectivity of $11 \%$. The jet biofuel yield under catalyst increased from $21.1 \%$ to $42 \%$ when the reaction temperature was increased from $370{ }^{\circ} \mathrm{C}$ to $390{ }^{\circ} \mathrm{C}$ [9]. Hydrogenated of rapeseed oil with three $\mathrm{Ni}$ Mo/Alumina hydrorefining catalyst in a flow reactor with temperature ranged from $260{ }^{\circ} \mathrm{C}$ to $340{ }^{\circ} \mathrm{C}$ and under pressure of $7 \mathrm{MPa}$. Reaction products were affected by the reaction condition. Mainly $\mathrm{C}_{17}$ and $\mathrm{C}_{18}$ alkanes and about 40 wt $\%$ of $\mathrm{i}$-alkanes $\mathrm{C}_{16}-\mathrm{C}_{18}$ under higher reaction temperature and hydrocarbons were detected. At lower temperature than $310{ }^{\circ} \mathrm{C}$, the final organic liquid products contained fatty acid and triglycerides [10]. $\mathrm{C}_{15}-\mathrm{C}_{20}$ range hydrocarbon was produced from hydrotreatment of jatropha oil over $\mathrm{NiMoLa} / \mathrm{Al}_{2} \mathrm{O}_{3}$ catalyst [11]. Hydrocracking of soybean oil using a NiMo/ZSM-5 catalyst was produced hydrocarbon fuel containing gasoline $\left(\mathrm{C}_{5}-\mathrm{C}_{12}\right)$, jet fuel $\left(\mathrm{C}_{8}-\mathrm{C}_{16}\right)$, and diesel fuel $\left(\mathrm{C}_{12}-\mathrm{C}_{22}\right)$. When the molar ratio of $\mathrm{Ni}$ to Mo was 0.5 , the highest hydrocarbon fuel yield was about $50 \%$ [12]. Catalytic fast pyrolysis of biomass with Fe/HZSM-5 catalyst was showed the yields of aromatic hydrocarbons were significantly increased with the rising of temperature from $500{ }^{\circ} \mathrm{C}$ to $600{ }^{\circ} \mathrm{C}$ and decreased with the increase from $600{ }^{\circ} \mathrm{C}$ to 800 ${ }^{\circ} \mathrm{C}$. It was reported that the addition of transition metals into HZSM-5 catalyst was used to reduce the yields of polycyclic aromatic hydrocarbons (PAHs) and improve the amounts of monocyclic aromatic hydrocarbons (MAHs) [1315]. HZSM-5 catalyst was used for the conversion of jatropha oil. It indicates ZSM-5 catalyst can produce gasoline along with kerosene and diesel range product [16].

Zeolites have been successfully used for the conversion of oxygenated organic compounds to hydrocarbons [17,18]. In particular zeolite HZSM-5 is well known as an efficient catalyst for the conversion of vegetable oil into hydrocarbon production due to its crystallinity, high surface area, strong acidity and high resistance to deactivation. In a reaction involving large molecules, such as: triglycerides conversion, catalyst accessibility, and textural properties have a strong effect on the overall catalytic performance $[19,20]$.

The addition of transition metal compounds to zeolite HZSM-5 is expected to modify the properties of the catalyst. The combination of metal with zeolite leads to bi-functional catalyst showing both acid and metal sites. The presence of some metals, such as nickel, is expected to promote hydrogenation / dehydrogenation reactions, enhancing the production of high quality hydrocarbon in biofuel [21].

The objective of this study was to investigate the feasibility of converting coconut oil into hydrocarbons, which could be applied in the fuels, by using bifunctional catalyst by incorporating nickel and iron in zeolite HZSM-5 catalyst. The different loading metal in catalyst has been characterized to obtain a better understanding of the relationship between catalyst performances. The influence of reaction temperature on the hydrocracking process was also studied. The Gas Chromatography-Mass Spectrometry (GC-MS) was to determine the composition and product yield of biofuel.

\section{Materials and Methods}

\subsection{Materials}

Coconut oil was commercially purchased from local market in East Java Province, Indonesia. Coconut oil was analyzed using by Gas Chromatography-Mass Spectrometry (GC-MS) with chromatogram as shown in Figure 4(a). Table 1 shown the composition of fatty acid in coconut oil. From analysis result, the main abundant component in coconut oil contains lauric acid of $45.16 \%$, myristic acid of $14.49 \%$, and oleic acid of $28 \%$. The main abundant component of coconut oil in this research has a high content of saturated fatty acid. This same result was reported by Zareh et al. [22] that the high composition of fatty acid in coconut oil is lauric acid of $45.16 \%$.

Table 1. Fatty acid composition of coconut oil analyzed by GC-MS

\begin{tabular}{ccc}
\hline Fatty acid & $\begin{array}{c}\text { Molecular } \\
\text { formula }\end{array}$ & Composition, \%wt \\
\hline Capric acid & $\mathrm{C}_{10} \mathrm{H}_{20} \mathrm{O}_{2}$ & 0.03 \\
Lauric acid & $\mathrm{C}_{12} \mathrm{H}_{24} \mathrm{O}_{2}$ & 45.16 \\
Myristic acid & $\mathrm{C}_{14} \mathrm{H}_{28} \mathrm{O}_{2}$ & 14.49 \\
Oleic acid & $\mathrm{C}_{18} \mathrm{H}_{34} \mathrm{O}_{2}$ & 28 \\
Stearic acid & $\mathrm{C}_{18} \mathrm{H}_{36} \mathrm{O}_{2}$ & 3.49 \\
others & - & 8.83 \\
\hline
\end{tabular}


The Commercial ZSM-5 zeolite powder was purchased from Zeolyst International USA $\left(\mathrm{SiO}_{2} / \mathrm{Al}_{2} \mathrm{O}_{3}\right.$ mole ratio: 40$)$. Nickel(II) nitrate hexahydrate $\left(\mathrm{Ni}\left(\mathrm{NO}_{3}\right)_{2} \cdot 6 \mathrm{H}_{2} \mathrm{O}\right)$ and iron(III) nitrate nonahydrate $\left(\mathrm{Fe}\left(\mathrm{NO}_{3}\right)_{3} .9 \mathrm{H}_{2} \mathrm{O}\right)$ was purchased from Merck with $98 \%$ purity.

\subsection{Methods}

\subsubsection{Preparation of catalyst}

$\mathrm{NH}_{4}$-ZSM-5 zeolite was modified into HZSM-5 through calcination process as previously reported at $550{ }^{\circ} \mathrm{C}$ for 5 hours [23,24]. The Ni-Fe/HZSM-5 catalyst was prepared via incipient wetness impregnation with the procedure as reported by a previous studies [23,24]. The amount of HZSM-5 zeolite was impregnated with aqueous solution of nickel(II) nitrate hexahydrate $\left(\mathrm{Ni}\left(\mathrm{NO}_{3}\right)_{2} .6 \mathrm{H}_{2} \mathrm{O}\right)$ and iron(III) nitrate nonahydrate $\left(\mathrm{Fe}\left(\mathrm{NO}_{3}\right)_{3} .9 \mathrm{H}_{2} \mathrm{O}\right)$ containing the required amount of nickel and iron. The first step is an aqueous solution of nickel(II) nitrate hexahydrate was introduced into HZSM-5 slowly and the catalyst was kept overnight in a desiccator and dried at $120{ }^{\circ} \mathrm{C}$ for $12 \mathrm{~h}$ in the oven. Then, the aqueous solution of iron (III) nitrate nonahydrate was introduced into Ni/HZSM-5 catalyst slowly and the catalyst was kept overnight in a desiccator and dried at $120{ }^{\circ} \mathrm{C}$ for $12 \mathrm{~h}$ in the oven. After being dried, the powder catalyst was calcined in $550{ }^{\circ} \mathrm{C}$ in the air for $3 \mathrm{~h}$ and reduced in flowing $\mathrm{H}_{2}$ at 550 ${ }^{\circ} \mathrm{C}$ for $2 \mathrm{~h}$, as reported in the previous study [13]. The Ni-Fe/HZSM-5 catalyst was obtained with different metal ratio of $1: 1$ and $1: 2$ for nickel-iron. The metals content measured by Energy Dispersive X-ray (EDX). The metals content was $3.19 \mathrm{wt} \%$ of $\mathrm{Ni}$ and $2.66 \mathrm{wt} \%$ of $\mathrm{Fe}$ of the catalyst weight. The catalyst is symbolized as $5 \%$ (Ni-Fe)/HZSM-5 catalyst. Other catalysts with different metal ratio obtained metal content was $3.75 \mathrm{wt} \%$ of $\mathrm{Ni}$ and 5.43 wt\% of Fe. The catalyst is symbolized as $10 \%$ (Ni-Fe)/HZSM-5 catalyst.

\subsubsection{Characterization of catalyst}

The Crystallinity of catalyst was assessed by X-Ray Diffraction (XRD: PANalytical X'Pert $\mathrm{PRO}$ ) with a $\mathrm{Cu}-\mathrm{Ka}$ radiation source operating at $40 \mathrm{kV}$ and $30 \mathrm{~mA}$. The sample was recorded in the range $2 \theta$ of 5 to $70^{\circ}$ with a step size 0.02 . The microstructure of surface morphology catalyst was characterized by SEM instrument (model: EVO MA10) equipped with EnergyDispersive X-ray analysis spectroscopy (EDAX) for analysis of metal dispersion of catalyst. $\mathrm{N}_{2}$ adsorption isotherms were measured using a Quantachrome NovaWinVersion 11.03. Before the measurements were made, samples were degassed in a vacuum at $300{ }^{\circ} \mathrm{C}$ for $3 \mathrm{~h}$. The surface area and pore size of the catalyst were investigated by Brunauer-Emmett-Teller (BET) and Barret-Joyner-Halenda (BJH) analyses. The total pore volumes were calculated from the volume of $\mathrm{N}_{2}$ adsorbed at a relative pressure, $p / p_{o}$, of 0.9907 .

\subsubsection{Hydrocracking process}

The hydrocracking experiment of coconut oil were carried out in a batch reactor (Parr USA, $600 \mathrm{~mL}$ ) equipped with a mechanical stirrer as reported by the previous study [23]. Figure 1 shows the equipment used to produce biofuel

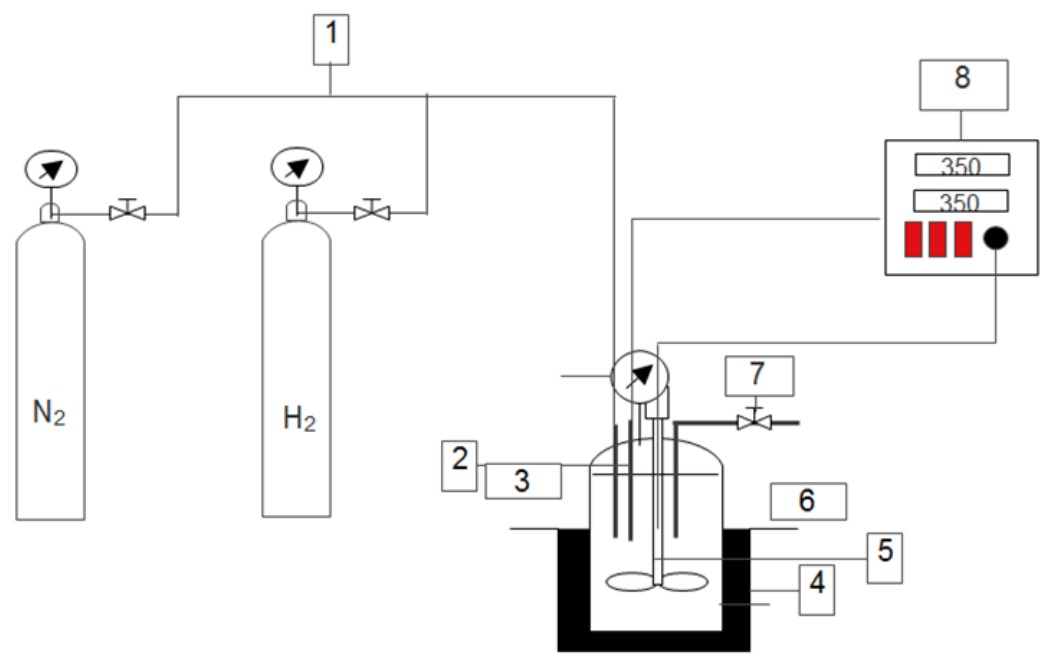

Figure 1. Schematic diagram of the hydrocracking process, consist of (1) Gas inlet tube, (2) Thermocouple, (3) Pressure gauge, (4) Furnace, (5) Stirrer, (6) Reactor, (7) tube gas outlet, (8) Controller 
from coconut oil by hydrocracking process using Ni-Fe/HZSM-5 catalyst. The experiments for each process the hydrocracking of coconut oil were conducted under the reaction conditions: temperature of $350-400{ }^{\circ} \mathrm{C}$, reactor pressure of $30 \mathrm{bar}$, the reaction time of $2 \mathrm{~h}$, coconut oil of $200 \mathrm{~mL}$, and catalyst mass of $2 \mathrm{~g}$. In each process, the coconut oil and catalyst were loaded in the reactor. Before each run, the reactor was injected with nitrogen gas for 10 minutes to remove any oxygen that might have been dissolved in an oil or in the reactor [25]. Then, the reactor flows with hydrogen gas for $1 \mathrm{~h}$ and the pressure was reached after flowing hydrogen. The reaction temperature was heated and kept it for $2 \mathrm{~h}$. After the hydrocracking process is over, the reaction is cooled to at room temperature. The liquid biofuel products were collected and analyzed by Gas Chromatography-Mass Spectrometry (GC-MS).

\subsubsection{Analysis of liquid biofuel products}

The chemical composition of liquid biofuel products was analyzed with standard GC: Agilent HP 6890 models 19091S-433, HP-5MS capillary column $30 \mathrm{~m} \times 250 \mathrm{~mm} \times 0.25 \mathrm{~mm}$. The initial pressure of 13.3 psi. The oven temperature was programmed from $150{ }^{\circ} \mathrm{C}$ with the heating rate of $4{ }^{\circ} \mathrm{C} / \mathrm{min}$ for $2 \mathrm{~min}$, then increased to $240{ }^{\circ} \mathrm{C}$ with the heating rate of 10 o $\mathrm{C} / \mathrm{min}$ for $11 \mathrm{~min}$. The chromatography peaks data were identified according to the National Institute of Standards and Technology (NIST02) and Wiley 275 library.

\section{Result and Discussion}

\subsection{Characterization of Catalyst}

The XRD patterns of HZSM-5 and Ni-Fe/HZSM-5 catalyst are shown in Figure 2. The peak characteristics of HZSM-5 structure were consistent with the previous study
[1,14,23,24]. The main peaks of HZSM-5 zeolite were presented at the $2 \theta$ of $7.9^{\circ}, 8.8^{\circ}, 23.1^{\circ}$, $23.4^{\circ}, 24^{\circ}$, and $24.46^{\circ}$ which are the specific

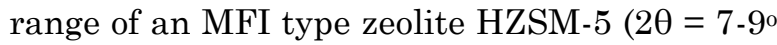
and $23-24^{\circ}$ ). The XRD patterns of Ni-Fe/HZSM5 catalyst show the similar characteristic peaks with HZSM-5 support. The results indicate no difference in crystallinity between HZSM-5 and Ni-Fe/HZSM-5 catalyst, suggesting that the zeolite framework structure did not affect after impregnation by $\mathrm{Ni}$ and Fe. However, when compared with HZSM-5 catalyst, the peak intensity of Ni-Fe/HZSM-5 catalyst decreased. It may be the incorporation of $\mathrm{Ni}$ and $\mathrm{Fe}$ on the HZSM-5 supports decreased the degree of crystallinity of the HZSM-5 as a support [13].

Figure 3 shows the surface morphologies of the HZSM-5, $5 \%$ (Ni-Fe)/HZSM-5, and $10 \%$ (Ni-Fe)/HZSM-5 catalyst. HZSM-5 powders appeared in agglomeration of particles on the top surface. The morphologies of Ni-Fe/HZSM-5 catalyst revealed the similar morphologies of HZSM-5 support. The particles of $\mathrm{Ni}$ and $\mathrm{Fe}$ could not be observed at this magnification be-

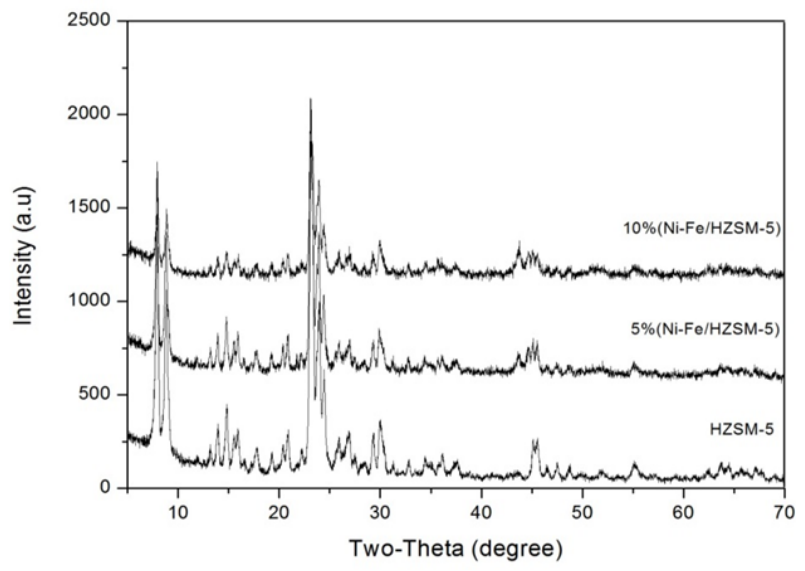

Figure 2. XRD Patterns of the HZSM-5, 5\% (Ni-Fe)/HZSM-5 and 10\% (Ni-Fe)/HZSM-5 catalyst
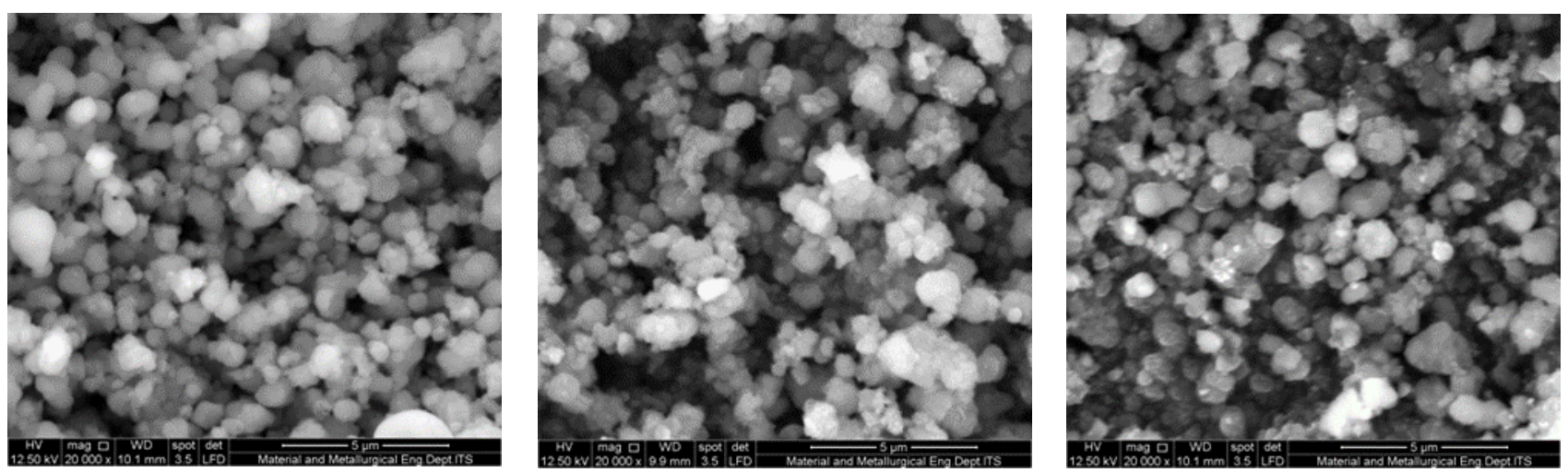

Figure 3. SEM of the HZSM-5, $5 \%$ (Ni-Fe)/HZSM-5, and $10 \%$ (Ni-Fe)/HZSM-5 catalyst 
cause they were presented in a small amount. The metal contents of $\mathrm{Ni}$ and $\mathrm{Fe}$ were determined by EDAX as shown in Table 2. It was found that the metal contents of $\mathrm{Ni}$ and $\mathrm{Fe}$ were detected in HZSM-5 support. The metal contents of $\mathrm{Ni}$ and $\mathrm{Fe}$ in Ni-Fe/HZSM-5 catalyst were a bit lower than calculated metal contents, which might be due to non-uniform distribution of the metal on the HZSM-5 support $[7,23,24]$.

The surface area, pore size, and total pore volume of the HZSM-5 and Ni-Fe/HZSM- 5 catalyst are displayed in Table 2. The HZSM-5 had a high surface area of $407.486 \mathrm{~m}^{2} / \mathrm{g}$. After impregnation by $\mathrm{Ni}$ and $\mathrm{Fe}$, the BET surface area decreased of 195.841 and $336.617 \mathrm{~m}^{2} / \mathrm{g}$. The BET surface area and total pore volume decreased significantly compared to HZSM-5 support after addition of metal ( $\mathrm{Ni}$ and $\mathrm{Fe}$ ) by incipient wetness impregnation method. For the $5 \%$ (Ni-Fe)/HZSM-5 catalyst, BET surface area, total pore volume, and pore size showed a decreasing trend. This indicated that some of the HZSM-5 pores and external surface of the HZSM-5 were deposited with $\mathrm{Ni}$ and Fe particles after impregnation. However, some of the mesopores were originated from the interparticle voids, which might be due to the aggregation of partial metal deposited on the surface of HZSM-5 [26]. For the $10 \%(\mathrm{Ni}-\mathrm{Fe}) / \mathrm{HZSM}-5$ catalyst, the BET surface area and total pore volume also decreased. These changes indicate that metal particles were successfully filled on the HZSM-5 surface and incorporated into HZSM-5 pore [1,7,14,23,24].

3.2 Hydrocracking Reaction of Coconut Oil over Ni-Fe/HZSM-5 Catalyst

3.2.1 Characterization of coconut oil and biofuel liquid products

Figure 4 shows the GC-MS profiles of coconut oil and biofuel liquid hydrocarbon product at temperature of $375{ }^{\circ} \mathrm{C}$. Figure 4 (a) shows that compounds contain coconut oil with the retention time of 10-24 min and it disappeared after the hydrocracking process. Figure 4 (b) and (c) shows chromatograms of liquid biofuel products after hydrocracking process at temperature of $375^{\circ} \mathrm{C}$. It shows that the activity of hydrocracking reaction was enhanced to produce the main chemical composition of hydrocarbon with the retention time of 2-7 min. It indicates triglycerides of coconut oil were converted into short chain molecules such as dodecane, tridecane, tetradecane, pentadecane, and heptadecane by cracking, cyclization, aromatization, isomerization reactions [24,27]. Figure 4 (b) and (c) shows the composition of various hydrocarbon in the biofuel product contains dodecane $\left(\mathrm{C}_{12}\right)$, tridecane $\left(\mathrm{C}_{13}\right)$, pentadecane $\left(\mathrm{C}_{15}\right)$, and heptadecane $\left(\mathrm{C}_{17}\right)$ were the four major products. The presence of pentadecane $\left(n-C_{15}\right)$ and heptadecane $\left(n-C_{17}\right)$ suggested that Decarboxylation and/or decarbonylation was the dominant reaction pathways in this process. This result is similar to the previous study [24,25].

3.2.2 Effect of temperature on biofuel liquid hydrocarbon composition

The effects of temperature on the chemical composition of the biofuel liquid hydrocarbon products over Ni-Fe/HZSM-5 catalyst are shown in Figure $5(\mathrm{a})$ and (b) at $350{ }^{\circ} \mathrm{C}, 375{ }^{\circ} \mathrm{C}$, and $400{ }^{\circ} \mathrm{C}$. In order to determine the effect of temperature on biofuel liquid hydrocarbon products, GC-MS was used to analyze the chemical composition of biofuel. The major chemical components consisted of n-paraffin, olefin, aromatics, cycloparaffin, isoparaffin, and other oxygenated compounds, such as carboxylic acid, ketones, and alcohol. The presence of organic compounds causes poor properties in the biofuel hydrocarbon including low heating value, high viscosity, instability, and corrosiveness [14,28,29].

As shown in Figure 5(a) the temperature significantly influence on biofuel liquid hydrocarbon composition with the $5 \%(\mathrm{Ni}-\mathrm{Fe}) / \mathrm{HZSM}$ -5 . At the temperature of $350{ }^{\circ} \mathrm{C}$, a carboxylic acid of 89.1 area\% was found in significant amounts. The presence of the carboxylic acid

Table 2. Properties of Ni-Fe/HZSM-5 catalyst

\begin{tabular}{lccccc}
\hline \multirow{2}{*}{ Catalyst } & $\begin{array}{c}\text { Surface area } \\
\left(\mathrm{m}^{2} / \mathrm{g}\right)\end{array}$ & $\begin{array}{c}\text { Pore Size } \\
(\mathrm{nm})\end{array}$ & $\begin{array}{c}\text { Total Pore Volume } \\
\left(\mathrm{cm}^{3} / \mathrm{g}\right)\end{array}$ & \multicolumn{2}{c}{ Element $(\mathrm{wt} \%)$} \\
\cline { 5 - 7 } HZSM-5 & 407.386 & 3.12 & 3.18 & $\mathrm{Ni}$ & $\mathrm{Fe}$ \\
\hline \% (Ni-Fe)/HZSM-5 & 195.841 & 3.07 & 3.04 & - & - \\
$10 \%(\mathrm{Ni}-\mathrm{Fe}) / \mathrm{HZSM}-5$ & 336.617 & 3.32 & 2.80 & 3.19 & 2.66 \\
\hline
\end{tabular}




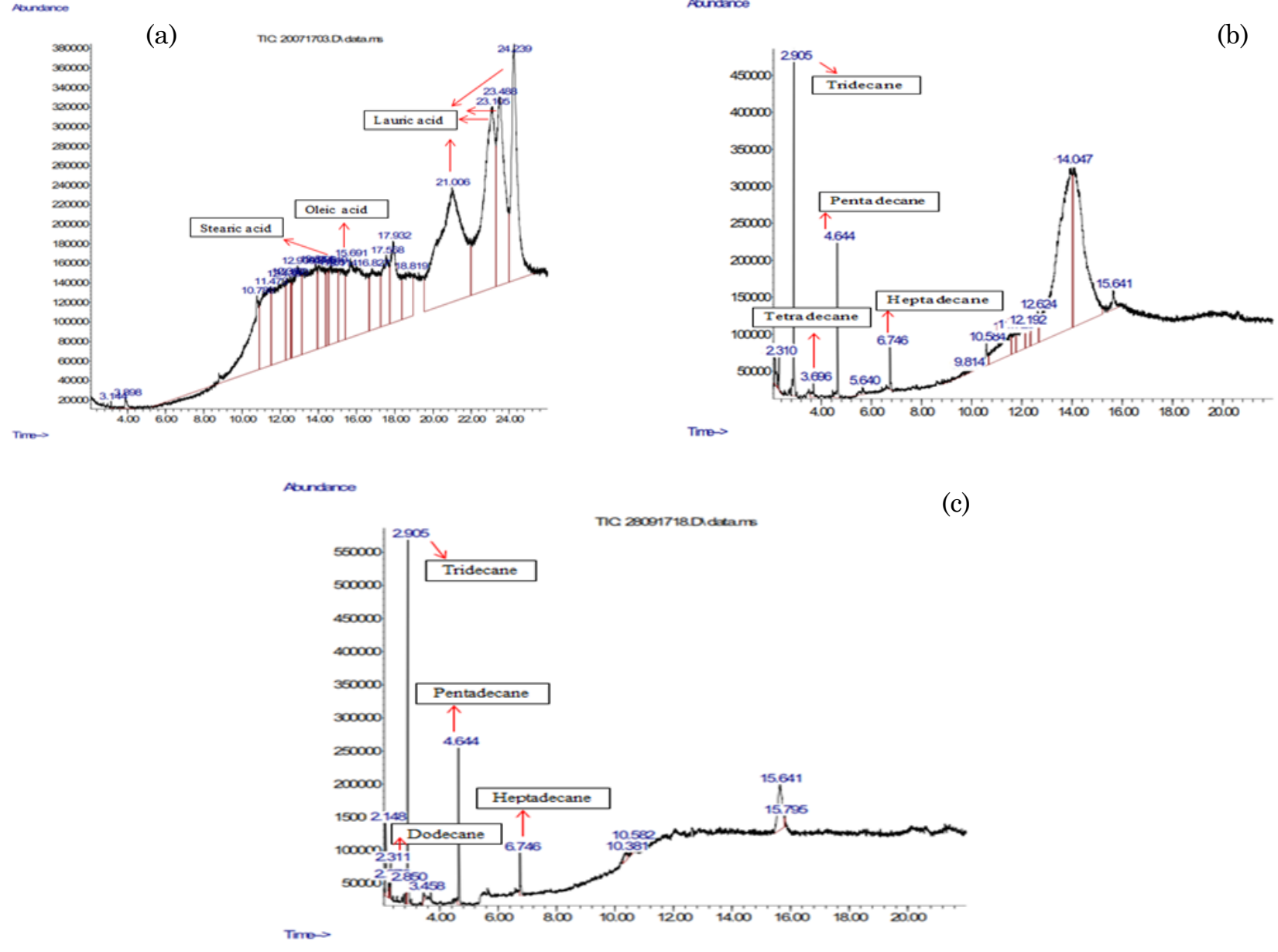

Figure 4. GC-MS spectra of (a) coconut oil, (b) biofuel liquid hydrocarbon product produced at $375{ }^{\circ} \mathrm{C}$ using $5 \%(\mathrm{Ni}-\mathrm{Fe}) / \mathrm{HZSM}-5$ catalyst, (c) biofuel liquid hydrocarbon product produced at $375{ }^{\circ} \mathrm{C}$ using 10 $\%(\mathrm{Ni}-\mathrm{Fe}) / \mathrm{HZSM}-5$ catalyst, under pressure 30 bar in a batch reactor. Saturated chain hydrocarbons (nparaffins) have the number of carbon atom from $\mathrm{C}_{12}$ to $\mathrm{C}_{22}$
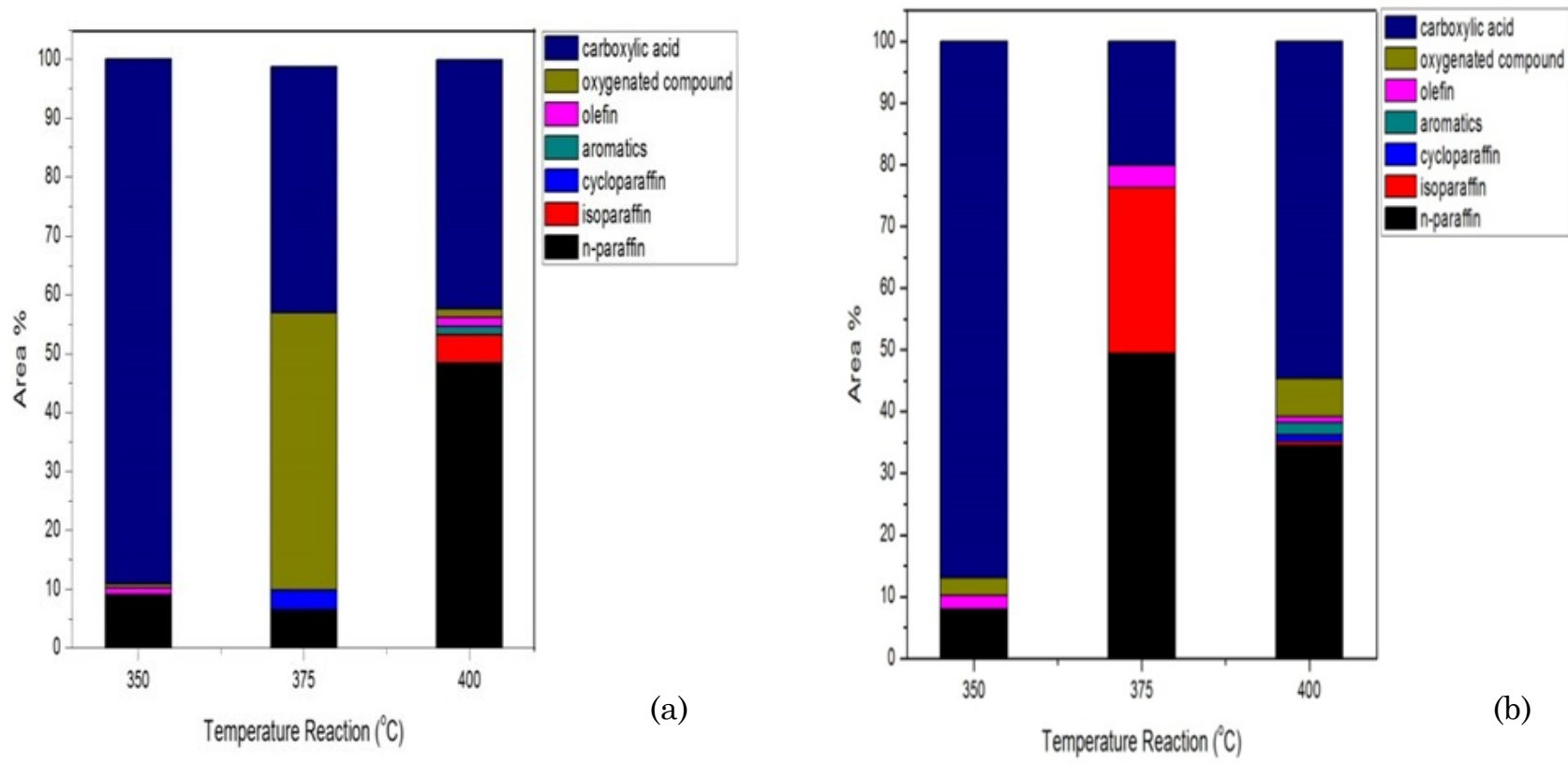

Figure 5. Effect of reaction temperature on chemical composition of biofuel liquid hydrocarbon from hydrocracking process using a) $5 \%$ (Ni-Fe)/HZSM-5, and b) 10\% (Ni-Fe)/HZSM- 5 catalyst 
and oxygenated compounds indicates that they have not completely converted to hydrocarbon compound at temperature of $350^{\circ} \mathrm{C}$. Figure 5(a) shows that the carboxylic acid decrease with the increasing temperature. This reaction was favorable at high temperature.

The rise of reaction temperature was completely converted carboxylic acid and oxygenated compounds to hydrocarbon compound. This decrease may be due to the conversion of oxygenated compounds into hydrocarbons caused by decarbonylation, hydrogenation, and cracking reactions [30]. The n-paraffins compounds, i.e. pentadecane $\left(n-C_{15}\right)$ and heptadecane (n$\mathrm{C}_{17}$ ), were produced in the reaction temperature of $350-400{ }^{\circ} \mathrm{C}$ through decarboxylation and decarbonylation reaction with $5 \%$ (Ni-Fe)/ZSM-5 catalyst. On the other hand, aromatic compounds were also found in the biofuel produced at a temperature of $400{ }^{\circ} \mathrm{C}$ with $5 \%$ (Ni-Fe)/HZSM-5 catalyst, i.e. octyl-benzene, and hexyl-benzene. It indicates, the incorporation of transition metals on/into HZSM-5 catalyst showed a bifunctional character which included acid and metal sites to increase the aromatization, and aliphatics reactions [14,24]. It has been reported that the hydrocracking temperatures have a great effect on the biofuel liquid hydrocarbon composition and hydrocracking conversion was increased with the increasing of the hydrocracking temperatures.

When the $10 \%(\mathrm{Ni}-\mathrm{Fe}) / \mathrm{HZSM}-5$ catalyst was used at a temperature of $375{ }^{\circ} \mathrm{C}$ the carboxylic acid and oxygenated compounds were completely converted to hydrocarbon compounds as shown in Figure 5(b). Carboxylic acids at this temperature were completely converted into $49.4 \%$ n-paraffin, $26.93 \%$ isoparaffin, $3.58 \%$ olefin, and $20.07 \%$ carboxylic acids. The composition of $n$-paraffin formed at this temperature contained the main components of pentadecane of 2.51 area\% dodecane, tridecane of 27.13 area\%, pentadecane of 14.27 area\%, heptadecane of 5.49 area\%. It was also different found in biofuel produced at a temperature of $375{ }^{\circ} \mathrm{C}$ with $5 \%$ (Ni-Fe)/HZSM-5 catalyst. Sotelo-Boyás et al. [31] stated that isoparaffin formation was influenced by the acid strength of the active site of HZSM-5. These results agree with those reported by Sotelo-Boyas et al. [31], who observed that the rising temperature decreased the formation of liquid components. This result was good performance in the formation of hydrocarbon compounds. Compared to the other studies, Cheng et al. [32] was produced biofuel with the hydrocarbon contents (18.99-28.60 \%) and high yield hydrocarbon
$28.60 \mathrm{wt} \%$. The content of esters in biofuel were $47.83-55.30 \%$.

The amount of metal loading catalyst increased to show the production of hydrocarbon were improved significantly with increasing temperature. The addition of metal is expected to modify the acid and textural properties of the HZSM-5 support to promote the cracking activity in terms of eliminating oxygenated compounds and increasing amount of hydrocarbon [14]. The oxygenated compounds was reduced when the temperature increase. The increasing ratio of Fe from 2.66 to $5.43 \%$ of the catalyst weight (by EDAX in Table 2) on ZSM-5 catalyst promoted the conversion of carboxylic acids to produce n-paraffin compounds. It produced the highest aliphatic compounds formation and amount of aromatic compounds. The results indicated that active site HZSM-5 play more important role in the formation of aliphatic compounds than aromatic production $[1,14,24]$. Via dehydrogenation, deoxygenation, cracking and reforming reactions, the catalyst can re-arrange the structure of molecules [33].

The HZSM-5 catalyst has an important feature of shape selectivity that avoids oversized vegetable oil molecules from diffusing into the catalyst pores and only allows product with small molecules to diffuse out of the catalyst pores. The relative narrow channels of zeolites lead to diffusional limitations and hinder the access to active catalytic sites for large reactants such as triglycerides [12]. The coconut oil triglycerides molecules went through the inside pores and/or the external surface of the catalyst to undergo the hydrocracking and the products formed after the cracking exited the HZSM-5 catalyst pores through another type of channels due to the size and shape of products [34]. The acid sites on the support HZSM-5 promoted the chemical reactions such as cracking and decarbonylation during the hydrocracking process. The combination of metal centers with the zeolite acid sites leads to the bifunctional character of the catalyst [12,35].

From biofuel liquid products as shown in Figure 5(a) and (b), hydrocarbon is the main valuable components. The contents of hydrocarbon in biofuel liquid products increased significantly in comparison with raw coconut oil. This is caused by HDC reactions including cracking, decarbonylation, decarboxylation, hydrocracking, hydrodeoxygenation and hydrogenation that converted oxygenated compounds to hydrocarbon components over Ni-Fe/HZSM-5 catalyst with different loading metal. Based on the results above, it can be 
concluded that the hydrocracking process of coconut oils with $10 \%(\mathrm{Ni}-\mathrm{Fe}) / \mathrm{HZSM}-5$ catalyst at $375{ }^{\circ} \mathrm{C}$ produced the greatest amount of aliphatic hydrocarbons. Hydrocarbon compounds such as aliphatic and aromatic were expected as products from hydrocracking process, due to high heating value properties $[2,14,36]$.

The incorporation of the transition metal such as $\mathrm{Ni}$ and $\mathrm{Fe}$ on/into HZSM-5 was expected to affect the deoxygenation and the hydrogen transfer during the hydrocracking process of coconut oil. The addition of Ni combined with acid site provided the ideal environment for oligomerization of small alkenes followed by cyclization and dehydrogenation, leading to greater rate of aromatic formation [37]. The presence of $\mathrm{Fe}$ showed excellent performance in the conversion of oxygenates and formation of an aromatic hydrocarbon. This result was similar to Thangalazhy-Gopakumar et al. [38], also reported and suggested that compared to ZSM-5 catalyst, the metals, such as: $\mathrm{Ni}, \mathrm{Co}$, Mo, or Pt, supported on ZSM-5 catalyst improved the yields of an aromatic hydrocarbon.

During the hydrocracking process, the high temperature may lead to cracking of vegetable oil into a small molecule: diglycerides, monoglycerides, and carboxylic acids, and oxygen may be removed from these compounds by the reactions: decarboxylation (1), decarbonylation (2), and hydrodeoxygenation (or dehydration/ hydrogenation) (3) [39]. From these results, it can be concluded that the effect temperature has an effect to produce aliphatic compounds and decreases the oxygenated compounds. In addition, the effect of temperature in hy- drocracking process has been positive in the conversion of the coconut oil triglycerides into biofuel liquid hydrocarbon products.

\subsubsection{Effect of reaction temperature on bio- kerosene/bio-gasoil yields}

The yield of biofuel liquid hydrocarbons, such as: bio-kerosene and bio-gasoil, during hydrocracking process over Ni-Fe/HZSM-5 catalyst with $5 \%$ and $10 \%$ metal loading at reaction temperature range from 350 to $400{ }^{\circ} \mathrm{C}$ as shown in Figure 6. As reported by Barron et al. [40], biofuel was description as bio-gasoline ( $\left.\mathrm{C}_{5}-\mathrm{C}_{9}\right)$, bio-kerosene $\left(\mathrm{C}_{10}-\mathrm{C}_{13}\right)$, and bio-gasoil $\left(\mathrm{C}_{14}-\mathrm{C}_{22}\right)$. The yield of bio-gasoil increase with increasing temperature as shown in Figure 6 (a) and (b). Increasing temperature causes more intensive cracking not only heavier molecules but also some bio-gasoil molecules are further cracked into lighter molecules.

Figure 6(a) shows with $5 \%$ (Ni-Fe)/HZSM-5 catalyst, yield of bio-gasoil was increased from $3.8 \%$ at temperature of $350{ }^{\circ} \mathrm{C}$ to $24.1 \%$ at temperature of $375{ }^{\circ} \mathrm{C}$. The yield of biokerosene changed from $3.5 \%$ at temperature of $350{ }^{\circ} \mathrm{C}$ to $22.2 \%$ at temperature of $400{ }^{\circ} \mathrm{C}$. It indicates that this hydrocracking process more suitable for bio-gasoil production rather than bio-kerosene or bio-gasoline production.

Figure 6(b) shows with 10\%(Ni-Fe)/HZSM-5 catalyst, yield of bio-gasoil was increased from $5.6 \%$ at temperature of $350{ }^{\circ} \mathrm{C}$ to $38.6 \%$ at temperature of $375{ }^{\circ} \mathrm{C}$. The yield of biokerosene changed from $3.8 \%$ at temperature of $350{ }^{\circ} \mathrm{C}$ to $27.5 \%$ at temperature of $375{ }^{\circ} \mathrm{C}$. This

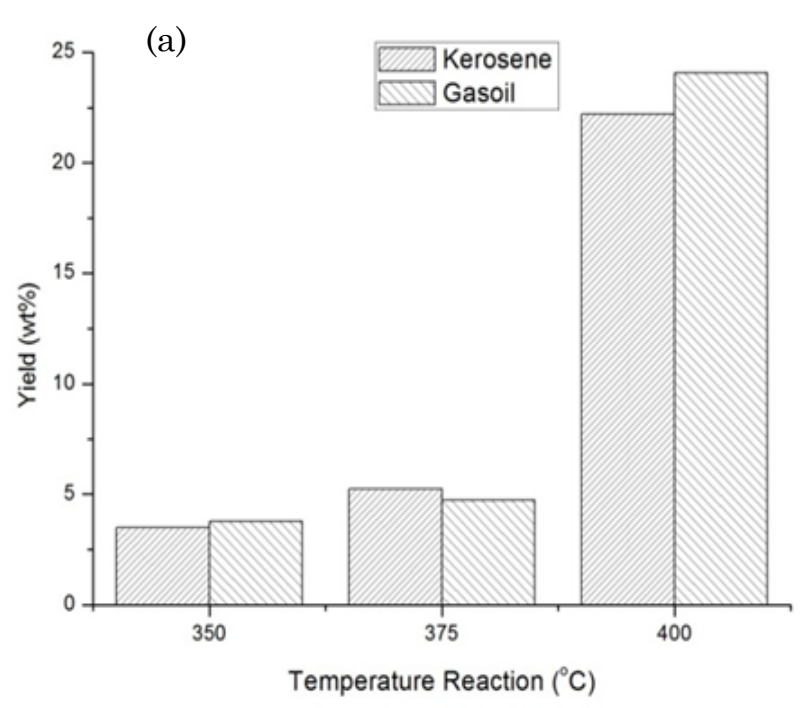

(b)

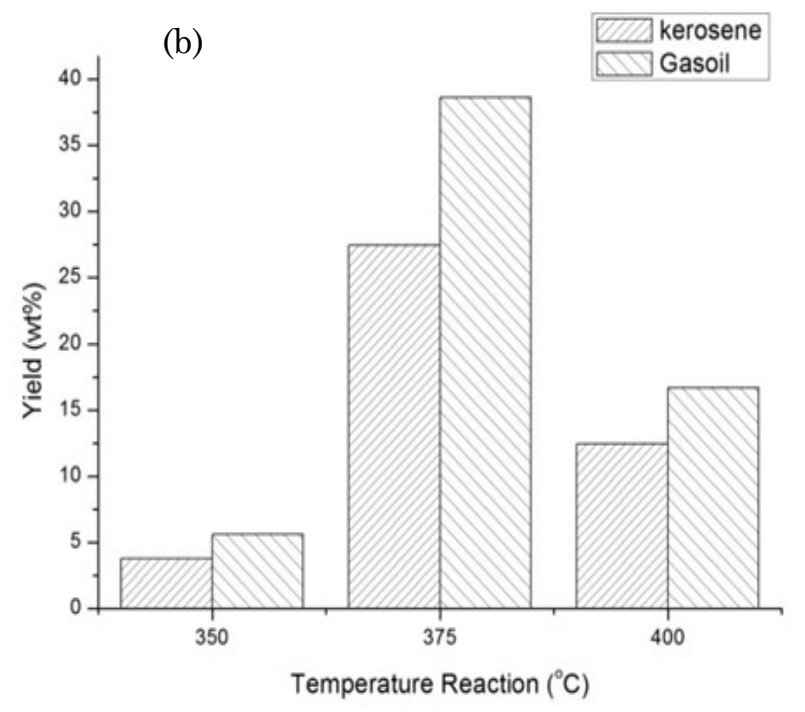

Figure 6. Effect of reaction temperature on kerosene/gasoil yields of biofuel liquid product from hydrocracking process using $5 \%(\mathrm{Ni}-\mathrm{Fe}) / \mathrm{HZSM}-5$ and $10 \%(\mathrm{Ni}-\mathrm{Fe}) / \mathrm{HZSM}-5$ catalyst 
suggested that hydrocracking reaction changed when the temperature increased. Therefore middle hydrocracking temperatures $\left(375{ }^{\circ} \mathrm{C}\right)$ promote bio-gasoil rather than bio-kerosene or bio-gasoline production. Pentadecane $\left(n-C_{15}\right)$ and heptadecane $\left(\mathrm{n}-\mathrm{C}_{17}\right)$ were the main abundant components found in bio-gasoil with 10 $\%(\mathrm{Ni}-\mathrm{Fe}) / \mathrm{HZSM}-5$ catalyst at temperature of $375{ }^{\circ} \mathrm{C}$. The decarboxylation/decarbonylation reaction occurs at temperatures above $350{ }^{\circ} \mathrm{C}$. This result is similar to Mohammad et al. [41] stated that the hydrocracking reaction was strongly influenced by the reaction temperature, pressure, liquid hourly space velocity, and the catalyst. Carboxylic acids were also significantly reduced after the addition of nickel and iron showing the removal of oxygenated compounds through the reaction of hydrodeoxygenation, decarboxylation, and decarbonylation.

Based on the above result, it can be concluded that the yield of bio-gasoil produced at $375{ }^{\circ} \mathrm{C}$ was the highest yield over $10 \%$ (Ni-Fe)/HZSM-5 catalyst. The reaction temperature affects the chemical composition of biofuel liquid hydrocarbon products which influences the hydrocarbon fuel yield. The high temperature would break long chain carboxylic acids into smaller molecular compounds. The active sites of HZSM-5 catalyst promoted the reactions such as cracking, decarboxylation, and decarbonylation [7]. It indicates that high reaction temperature favored the cracking activity of HZSM-5 and had an effect on the yield of upgraded coconut oil, consistent with previous study $[7,42]$. On the other hand, with the increase of temperatures, the degree of cracking and isomerization selectivity increased. In summary, the acid strength of HZSM-5 plays important role in the transformation of triglycerides into biofuel in the range of alkanes [43].

\section{Conclusions}

The Ni-Fe/HZSM-5 catalyst was applied to the hydrocracking process to produce biofuel in a batch reactor. The effect of temperature on the chemical compositions and yields were investigated by GC-MS. The results from the GCMS analysis showed that the hydrocracking reaction over $10 \%(\mathrm{Ni}-\mathrm{Fe}) / \mathrm{HZSM}-5$ catalyst at $375{ }^{\circ} \mathrm{C}$ obtained the highest hydrocarbon content (contained $49.4 \% \mathrm{n}$-paraffin, $26.93 \%$ isoparaffin, $3.58 \%$ olefin) and the highest yield of bio-gasoil $38.6 \%$ in the biofuel liquid hydrocarbon. The increasing ratio of $\mathrm{Fe}$ from 2.66 to $5.43 \%$ of the catalyst weight (by EDAX in Table 2) on ZSM-5 catalyst promoted the conversion of carboxylic acids to produce n-paraffin compounds. Aliphatic and aromatic compounds were produced from this process. Pentadecane $\left(\mathrm{n}-\mathrm{C}_{15}\right)$ and heptadecane $\left(\mathrm{n}-\mathrm{C}_{17}\right)$ were the most abundant hydrocarbon compounds in biofuel liquid hydrocarbon. Decarboxylation and/or decarbonylation was the dominant reaction pathways in this process. The rise of reaction temperature was strongly influenced to convert carboxylic acid and oxygenated compounds into hydrocarbon compounds.

\section{Acknowledgments}

The authors would like gratefully acknowledge to DRPM, Directorate General of Research and Development, the Ministry of research, Technology and Higher Education of Indonesia for the research grant supporting in this research. The authors also would like appreciate to the head of chemical reaction engineering laboratory for the facilities, and also thanks for the crews of laboratory, i.e. Afrida Nur Aini and Irene Fransisca Theresia, Department of Chemical Engineering, Faculty of Industrial Technology, Sepuluh Nopember Institute of Technology.

\section{References}

[1] Vichaphund, S., Aht-ong, D., Sricharoenchaikul, V., Atong, D. (2014). Catalytic Upgrading Pyrolysis Vapors of Jatropha Waste Using Metal Promoted ZSM-5 Catalysts: An Analytical PY-GC/MS. Renewable Energy, 65: 70-77.

[2] Stefanidis, S.D., Kalogiannis, K.G., Iliopoulou, E.F., Lappas, A.A., Pilavachi, P.A. (2011). In-situ Upgrading of Biomass Pyrolysis Vapors: Catalyst Screening on a Fixed Bed Reactor. Bioresource Technology, 102(17): 8261-8267.

[3] Yu, F., Gao, L., Wang, W., Zhang, G., Ji, J. (2013). Bio-fuel Production from the Catalytic Pyrolysis of Soybean Oil over Me-Al-MCM-41 ( $\mathrm{Me}=\mathrm{La}, \mathrm{Ni}$ or $\mathrm{Fe}$ ) Mesoporous Materials. Journal of Analytical and Applied Pyrolysis, 104: 325-329.

[4] Gosselink, R.W., Hollak, S.A., Chang, S.W., Van Haveren, J., De Jong, K.P., Bitter, J.H., Van Es, D.S. (2013). Reaction Pathways for the Deoxygenation of Vegetable Oils and Related Model Compounds. Chem. Sus. Chem, 6(9): 1576-1594.

[5] Donnis, B., Egeberg, R.G., Blom, P., Knudsen, K.G. (2009). Hydroprocessing of Bio-oils and Oxygenates to Hydrocarbons. Understanding the Reaction Routes. Top. Catal, 52(3): 229240 . 
[6] Ketaren, S. (1985). Introduction to Essential Oils Technology. Balai Pustaka, Jakarta. 142143.

[7] Zhao, X., Wei, L., Julson, J., Gu, Z., Cao, Y. (2015). Catalytic Cracking of Inedible Camelina Oils to Hydrocarbon Fuels over Bifunctional Zn/ZSM-5 Catalysts. Korean J. Chem. Eng., 32(8): 1528-1541.

[8] Shahinuzzaman, M., Yaakob, Z., Ahmed, Y. (2017). Non-sulphide Zeolite Catalyst for BioJet Fuel Conversion. Renewable and Sustainable Energy Reviews, 77: 1375-1384

[9] Li, T., Cheng, J., Huang, R., Yang, W., Zhou, J., Cen, K. (2016). Hydrocracking of Palm Oil to Jet Biofuel over Different Zeolites. International Journal of Hydrogen Energy, 41(47): 21883-21887.

[10] Šimáček, P., Kubička, D., Šebor, G., Pospíšil, M. (2009). Hydroprocessed Rapeseed Oil as a Source of Hydrocarbon-Based Biodiesel. Fuel, 88(3), 456-460.

[11] Liu, J., Liu, C., Zhou, G., Shen, S., Rong, L. (2012). Hydrotreatment of Jatropha Oil over $\mathrm{NiMoLa} / \mathrm{Al}_{2} \mathrm{O}_{3}$ Catalyst. Green Chem, 14: 2499-2505.

[12] Wang, H., Yan, S., Salley, S.O., Ng, K.S. (2012). Hydrocarbon Fuels Production from Hydrocracking of Soybean Oil Using Transition Metal Carbides and Nitrides Supported on ZSM-5. Ind. Eng. Chem. Res, 51(30): 10066-10073.

[13] Sun, L., Zhang, X., Chen, L. Xie, X. (2016). Comparision of Catalytic Fast Pyrolysis of Biomass to Aromatic Hydrocarbons over ZSM-5 and Fe/ZSM-5 Catalysts. Journal of Analytical and Applied Pyrolysis, 121: 342-346.

[14] Vichaphund, S., Aht-ong, D., Sricharoenchaikul, V., Atong, D. (2015). Production of Aromatic Compounds from Catalytic Fast Pyrolysis of Jatropha Residues Using Metal/HZSM5 Prepared by Ion-Exchange and Impregnation Methods. Renewable Energy, 79: 28-37.

[15] French, R., Czernik, S. (2010). Catalytic Pyrolysis of Biomass for Bio-fuels Production. Fuel Processing Technology, 91: 25-32.

[16] Sharma, R.K., Anand, M., Rana, B.S., Kumar, R., Farooqui, S.A., Sibi, M.G., Sinha, M.K. (2012). Jatropha-Oil Conversion to Liquid Hydrocarbon Fuels Using Mesoporous Titanosilicate Supported Sulfide Catalysts. Catalysis today, 198: 314-320.

[17] Chang, C.D., Silvestri, A.J. (1977). The Conversion of Methanol and Other Compounds to Hydrocarbons over Zeolite Catalysts. J. Catalysis, 47: 249-259.

[18] Weisz, P.B., Haag, W.O., Rodewald, P.G. (1979). Catalytic Production of High Grade Fuel (Gasoline) from Biomass Compounds by
Shape Selective Catalysis. Science, 206(4414): 57-8.

[19] Botas, J.A., Serrano, D.P., Garcia, A., Ramos, R. (2014). Catalytic Conversion of Rapeseed Oil for the Production of Raw Chemicals, Fuels and Carbon Nanotubes over NiModified Nanocrystalline and Hierarchical ZSM-5. Applied Catalyst B: Environmental, 145: 205-215.

[20] Botas, J.A., Serrano, D.P., García, A., de Vicente, J., Ramos, R. (2012) Catalytic Conversion of Rapeseed Oil into Raw Chemicals and Fuels over Ni-and Mo-Modified Nanocrystalline ZSM-5 Zeolite. Catalysis Today, 195: 5970.

[21] Maia, A.J., Louis, B., Lam, Y.L., Pereira, M.M. (2010). Ni-ZSM-5 Catalysts: Detailed Characterization of Metal Sites for Proper Catalyst Design. Journal of Catalysis, 269: 103-109.

[22] Zareh, P., Asghar Zare, A., Ghobadian, B. (2017). Comparative Assessment of Performance and Emission Characteristics of Castor, Coconut and Waste Cooking Based Biodiesel as Fuel in a Diesel Engine. Energy, 139: 883-894.

[23] Al-Muttaqii, M., Marlinda, L., Roesyadi, A., Danawati, H.P. (2017). Co-Ni/HZSM-5 Catalyst for Hydrocracking of Sunan Candlenut Oil (Reutealis trisperma (Blanco) Airy Shaw) for Production of Biofuel. J. Pure App. Chem. Res., 6(2): 84-92.

[24] Marlinda, L., Al-Muttaqii, M., Gunardi, I., Roesyadi, A., Danawati, H.P. (2017). Hydrocracking of Cerbera manghas Oil with CoNi/HZSM-5 as Double Promoted Catalyst, Bull. Chem. React. Eng. Cat., 12(2): 167-184.

[25] Veriansyah, B., Han, J.Y., Kim, S.K., Hong, S., Kim, Y.J., Lim, J.S., Shu, Y.W., Oh, S., Kim, J. (2012). Production of Renewable Diesel by Hydroprocessing of Soybean Oil: Effect of Catalysts. Fuel, 94: 578-585.

[26] Zhao, X., Wei, L., Cheng, S., Kadis, E., Cao, Y., Boakye, E., Gu, Z., Julson, J. (2016). Hydroprocessing of Carinata Oil for Hydrocarbon Biofuel over $\mathrm{Mo}-\mathrm{Zn} / \mathrm{Al}_{2} \mathrm{O}_{3}$. Applied Catalysis B: Environmental, 196: 41-49.

[27] Pinto, F., Varela, F.T., Gonçalves, M., Neto André, R., Costa, P., Mendes, B. (2014). Production of Bio-Hydrocarbons by Hydrotreating of Pomace Oil. Fuel, 116: 84-93.

[28] Czernik, S., Bridgwater, A.V. (2004). Overview of Application of Biomass Fast Pyrolysis Oil. Energy Fuel, 18: 590-598.

[29] Bridgwater, A.V. (2012). Review of Fast Pyrolysis of Biomass and Product Upgrading. Biomass Bioenergy, 38: 68-94. 
[30] Idem, R.O., Katikaneni, S.P.R., Bakhshi, N.N. (1996). Thermal Cracking of Canola Oil: Reaction Products in the Presence and Absence of Steam. Energy \& Fuels, 10(16): 1150-1162.

[31] Sotelo-Boyás, R., Liu, Y., Minowa, T. (2011). Renewable Diesel Production from the Hydrotreating of Rapeseed Oil with Pt/Zeolite and $\mathrm{NiMo} / \mathrm{Al}_{2} \mathrm{O}_{3}$ Catalysts. Ind. Eng. Chem. Res., 50(5): 2791-2799.

[32] Cheng, S., Wei, L., Julson, J., Muthukumarappan, K., Kharel, P.R. (2017). Upgrading Pyrolysis Bio-Oil to Hydrocarbon Enriched Biofuel over Bifunctional Fe-Ni/HZSM-5 Catalyst in Supercritical Methanol. Fuel Processing Technology, 167: 117-126.

[33] Yildiz, G., Ronsse, F., Vercruysse, J., Daels, J., Ezgi, T.H., Van Geem, K.M., Marin, G.B., Duren, R., Prins, W. (2016). In Situ Performance of Various Metal Doped Catalysts in Micro-Pyrolysis and Continuous Fast Pyrolysis. Fuel Processing Technology, 144: 312-322.

[34] Liu, H., Cao, L., wei, B., Fan, Y., Shi, G.,Bao, X. (2012). In-situ Synthesis and Catalytic Properties of ZSM-5/Rectorite Composites as Propylene Boosting Additive in Fluid Catalytic Cracking Process. Chinese Journal of Chemical Engineering, 20(1): 158-166.

[35] Rahimi, N., Karimzadeh, R. (2011). Catalytic Cracking of Hydrocarbons over Modified ZSM-5 Zeolites to Produce Light Olefins: A Review. Applied Catalysis A: General, 398: 117.

[36] Marlinda, L., Al-Muttaqii, M., Roesyadi, A., Danawati, H.P. (2016). Production of Biofuel by Hydrocracking of Cerbera Manghas Oil Using Co-Ni/HZSM-5 Catalyst : Effect of Reaction Temperature. J. Pure App. Chem. Res., 5(3): 189-195.
[37] Iliopoulou, E.F., Stefanidis, S.D., Kalogiannis, K.G., Delimitis, A., Lappas, A.A., Triantafyllidis, K.S. (2012). Catalytic Upgrading of Biomass Pyrolysis Vapors Using Transition Metal-Modified ZSM-5 Zeolite. Appl. Catal. B., 127: 281-290.

[38] Thangalazhy-Gopakumar, S., Adhikari, S., Gupta, R.B. (2012). Catalytic Pyrolysis of Biomass over HZSM-5 under Hydrogen Process. Energy Fuel, 26: 5300-5306.

[39] Huber, G.W., O’Connor, P., Corma, A. 2007. Processing Biomass in Conventional Oil Refineries: Production of High Quality Diesel by Hydrotreating Vegetable Oils in Heavy Vacuum Oil Mixtures. Applied Catalysis A: General, 329: 120-129.

[40] Barrón, C.A.E., Melo-Bandaa, J.A., Dominguez, E.J.M., Hernández, M.E., Silva, R.R., Reyes, T.A.I., Meraz, M.M.A. (2011). Catalytic Hydrocracking of Vegetable Oil for Agrofuels Production using Ni-Mo, Ni-W, Pt and TFA Catalysts Supported on SBA-15. Catalysis Today, 166: 102-110.

[41] Mohammad, M., Kandaramath Hari, T., Yaakob, Z., Chandra Sharma, Y., Sopian, K., (2013). Overview on the Production of Paraffin Based-Biofuels via Catalytic Hydrodeoxygenation. Renew. Sustain. Energy. Rev., 22: 121-132.

[42] Mo, N., Savage, P.E. (2014). Hydrothermal Catalytic Cracking of Fatty. Acids with HZSM-5. ACS. Sustain. Chem. Eng., 2(1): 8894.

[43] Liu, S., Zhu, Q., Guan, Q., He, L., Li, W. (2015). Bio-aviation Fuel Production from $\mathrm{Hy}$ droprocessing Castor Oil Promoted by the Nickel-Based Bifunctional Catalysts. Bioresource Technology, 183: 93-100. 